\title{
NEUROSCHISTOSOMIASIS DUE TO Schistosoma mansoni: A REVIEW OF PATHOGENESIS, CLINICAL SYNDROMES AND DIAGNOSTIC APPROACHES
}

\author{
Cristiana M. NASCIMENTO-CARVALHO(1) \& Otávio A. MORENO-CARVALHO(2)
}

\begin{abstract}
SUMMARY
Neuroschistosomiasis (NS) is the second most common form of presentation of infection by the trematode, Schistosoma mansoni. Granulomatous inflammatory reaction occurs as a result of schistosome eggs being transmitted to spinal cord or brain via the vascular system, or by inadvertent adult worm migration to these organs. The two main clinical syndromes are spinal cord neuroschistosomiasis (acute or subacute myelopathy) and localized cerebral or cerebellar neuroschistosomiasis (focal CNS impairment, seizures, increased intracranial pressure). Presumptive diagnosis of NS requires confirming the presence of $S$. mansoni infection by stool microscopy or rectal biopsy for trematode eggs, and serologic testing of blood and spinal fluid. The localized lesions are identified by signs and symptoms, and confirmed by imaging techniques (contrast myelography, CT and MRI). Algorithms are presented to allow a stepwise approach to diagnosis.
\end{abstract}

KEYWORDS: Neuroschistosomiasis; Diagnosis; Cerebrospinal fluid; Magnetic resonance imaging; Schistosoma mansoni.

\section{INTRODUCTION}

Schistosomiasis associated with Schistosoma mansoni infection is endemic in the Caribbean islands, the Middle East, South America, and Africa and may be imported to any other area in the world via immigration and travel to foreign lands. It is estimated that between 200 and 300 million people are infected by $S$. mansoni worldwide $^{62}$. In Brazil, it is estimated that between 10 and 12 million people have schistosomiasis mansoni ${ }^{25}$. Spread of the disease from rural to periurban regions has been recently described ${ }^{3}$. The infection is primarily localized in the digestive system, but the nervous system is the second most common involved site ${ }^{1}$. PITTELLA \& LANA-PEIXOTO ${ }^{43}$ recorded that ova were found in the brain of $26 \%$ of patients who have hepatosplenic $S$. mansoni infection. A study in Tanzania indicated that $6 \%$ of non-traumatic myelopathies in endemic areas may be attributable to schistosomiasis ${ }^{53}$.

The purposes of this study are to review the pathogenesis and clinical syndromes of neuroschistosomiasis (NS), and to present a stepwise diagnostic approach to its management.

\section{PATHOGENESIS}

Humans are the principal definitive host for S. mansoni; adult worms inhabit the portal veins where eggs are laid beginning 4-8 weeks after infection ${ }^{32}$. NS occurs when ova and or adult worms reach the central nervous system (CNS). Two mechanisms have been postulated for this process: the ova are carried to the CNS through arterial or retrograde venous blood flow via the valveless perivertebral plexus of Batson, being deposited anywhere along the path of the blood flow ${ }^{43}$, or the ova are deposited in situ after the anomalous migration of adult worms ${ }^{46}$. The first mechanism would account for the sparse distribution of ova in many patients, and the second mechanism is supported by the occasional finding of adult worms within the leptomeningeal veins and by the confined area of ova deposition described in the tumoral form of schistosomiasis. The carriage of schistosome ova into the valveless venous plexus may be augmented when the intra-abdominal pressure rises, for example during defaecation or coughing ${ }^{45}$. The greater incidence of myelopathy at the lumbosacral regions is probably explained by this mechanism ${ }^{54}$. NS can be present in the early stages of the infection, while the patient is still asymptomatic (non-toxaemic form), during the slow and gradual evolution of the disease to its chronic forms, or concomitantly with the chronic intestinal, hepatointestinal or hepatosplenic forms ${ }^{40,46}$. In the early postinfective stage, especially in non-immune subjects, neurological symptoms may occasionally appear in the Katayama syndrome which is attributed to an immunological reaction to cercariae or schistosomula or ova ${ }^{54}$.

The granulomatous reaction of the host to the presence of the ova is the major factor in the pathogenesis of schistosomiais ${ }^{45}$. Granulomas are strictly mediated by CD4+ T helper (Th) cells specific for egg antigens; the best studied and most abundant egg component is the Sm-p40 antigen. In addition to it, Sm-PEPCK and Sm-TPx-1 have 


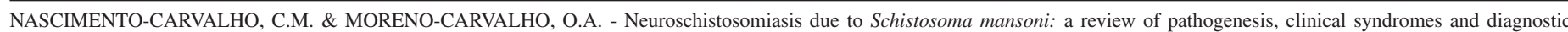
approaches. Rev. Inst. Med. trop. S. Paulo, 47(4):179-184, 2005.

been described and Sm-p40 and Sm-PEPCK have demonstrated immunogenicity in humans ${ }^{57}$. Egg antigens are host-immunogenic glycoproteins that include those that are actively secreted and those that are released after the egg's death and disintegration; their immunogenicity and pathogenicity will vary in accordance with genetically determined host factors ${ }^{57}$. For many years, numerous efforts have been made by several laboratories to elucidate the immunogens present in soluble schistosome egg antigens (SEA) preparations which include at least 30 components that are strong immunogens; it is supposed that several of them likely contribute to sensitizing the host for granuloma formation, although the precise number is presently unknown ${ }^{57}$. Granuloma formation can occur in environments dominated by either Th- 1 or Th- 2 type cytokines ${ }^{39}$. Th- 1 cytokine profile has been preferentially associated with hepato-splenic schistosomiasis ${ }^{34}$ whereas patients with intestinal disease present elevated anti-inflammatory Th2-type cytokine ${ }^{4}$. The immune response to the antigens released from the ova is at a maximum intensity in the early stages of infection, leading to the formation of necrotic-exudative granulomas and the immune response declines over the course of the infection ${ }^{9}$. The spontaneous down-modulation of the granulomatous response was extensively analyzed; at the peak of granulomatous response (eight to 10 weeks), delayed dermal reaction and production of cytokines, macrophage inhibitory factor, and eosinophil stimulation promoter were strong; cytokines production declines concurrently with the waning of the granulomatous inflammation (from 12 weeks onward); whereas the granulomatous responses wax and wane, fibrosis is cumulative and mostly irreversible ${ }^{6}$. Thus, the three stages of the granulomatous reaction (necrotic-exudative, productive and fibrotic) are strictly dependent on the evolution of the immunological response and the interaction between host and infection.

The most common site of clinically significant NS is the spinal $\operatorname{cord}^{9,12,13,54,56}$. The prominent lateral spine of $S$. mansoni's egg probably hampers the egg from reaching the brain ${ }^{9,16}$. The pathological findings include a granulomatous intramedullary mass in the caudal spinal cord, radicular involvement with granulomatous changes surrounding the conus medullaris and nerve roots of the cauda equina, necrotic exudative granulomas and haemorrhage, and asymptomatic deposition of ova in the spinal $\operatorname{cord}^{46,54}$. Vascular changes have included focal or diffuse vasculitis and rarely fibrinoid necrosis ${ }^{54}$. The second most common site of NS is the cerebellum ${ }^{22,27,50}$, although involvement of other confined cerebral areas, such as occipital and parietal lobes have been described $^{18,30,46}$. S. mansoni ova were observed in the meninges, cerebral cortex, cerebellum, choroid plexus, basal ganglia and white matter eliciting a granulomatous response. Nevertheless, clinically significant granulomas have rarely been described in the brain $^{54}$. It is notable that myelopathy is rarely encountered when hepatosplenic schistosomiasis is present, though in these cases, especially when cor pulmonale is present, the deposition of $S$. mansoni ova in the brain is markedly increased; hepatosplenic schistosomiais was present in most reported cases of $S$. mansoni encephalopathy ${ }^{43}$. Portopulmonary anastomoses through the azygos veins allow ova and adult schistosomes to reach the lungs and ova laid there could enter pulmonary veins and become arterial emboli ${ }^{54}$. In summary, it is believed that the deposition of $S$. mansoni ova in the brain is more common in the hepatosplenic form of schistosomiais mansoni, although the clinical manifestations are quite rare in this situation and the deposition of $S$. mansoni ova may occur in any form of the disease ${ }^{56}$.

\section{CLINICAL SYNDROMES}

The asymptomatic form of NS is far more frequent than the symptomatic ones ${ }^{16,46,54,56}$. All the symptomatic forms of NS are more prevalent among young men which can be partly explained by the fact that the incidence of schistosomiasis is usually higher in males who in rural areas are more likely to be exposed to schistosome-infected water during childhood and in the course of their work ${ }^{16,54}$. Patients' ages have ranged from one to 82 years (mean 26 years or $37 \pm 16$ years in different studies) $)^{33,35,54,56}$. Schistosomal myelopathy tends to occur early after infection and is more likely to be symptomatic than cerebral schistosomiasis ${ }^{9}$. The clinical syndrome of spinal NS is usually an acute or subacute myelopathy, with or without polyradiculitis, causing lumbosacral and lower limbs pain, paraparesis or paraplegia, bowel and bladder sphincter dysfunction, and sensory, sexual and reflexic disturbances ${ }^{42,46,54,56}$. In a review by FERRARI ${ }^{13}, 99 \%$ of the patients present with leg weakness, $85 \%$ with decreased sensation in the lower thoracic dermatomes, $66 \%$ with decreased sensation in lumbar dermatomes, $71 \%$ with low back or leg pain, and $90 \%$ with bladder dysfunction; $31 \%$ of the patients have mostly medullary involvement, with a clinical picture of transverse myelitis; $14 \%$ have isolated involvement of the conus medullaris and cauda equina; and $56 \%$ have myeloradiculopathy or a combination of myelitis with conus and cauda equina syndrome. In the aforementioned review, the level of the lesion was described in $214(92.6 \%)$ of 231 cases reviewed and the frequency was: low thoracic (T6-T12) $41.6 \%$, lumbar $33.2 \%$, lumbar, sacral and cauda equina $9.8 \%$, high thoracic (T1-T5) $7.0 \%$, sacral $5.1 \%$, radicular (cauda equina) $1.9 \%$ and cervical $1.4 \%{ }^{13}$. In a series of prospectively evaluated 63 cases with presumptive spinal NS, FERRARI et al. ${ }^{17}$ reported progressive worsening with new clinical manifestation being added to the previous one; nevertheless, spontaneous improvement of pain was observed in some patients as the remaining manifestations set in; the myeloradicular symptoms were maximal within two weeks of their onset in most cases $(69.8 \%)$, particularly within the first week. Four clinical forms of spinal NS are classically described: granulomatous (expansive lesion due to granulomatous reaction around the eggs and destruction of adjacent tissue), myelitic (necrosis, vacuolization and atrophy of the nervous tissue with scarce granulomas, presenting as progressive transverse myelitis with adverse outcome), radicular (granulomas are formed on the surface of the nerve roots, mainly in the cauda equina and patients present asymmetric sensory and motor disturbance), vascular (immunological inflammation of the anterior spinal artery $)^{13,56}$. The granulomatous form is the most frequent one and the concomitance between the granulomatous and radicular forms is very common ${ }^{56}$. The clinical picture of spinal NS may be occasionally less suggestive of the entity, mainly when higher segments of the spinal cord are involved or when there is a slower progression of the neurological signs and symptoms ${ }^{16}$.

Although the majority of cerebral egg deposition is asymptomatic ${ }^{22}$, clinical manifestations of cerebral NS include seizures associated with an increase in intra-cranial pressure and focal CNS signs, depending on the site of the cerebral lesion, caused by the masses produced by the granulomas ${ }^{27}$. Headache, papilledema, visual abnormalities, speech disturbances, nystagmus and ataxia are common manifestations ${ }^{16}$. Duration of the symptoms varies from a few weeks to more than one year ${ }^{44}$. It is also important to comment a different form of presentation: acute encephalitis or encephalomyelitis together with or immediately 


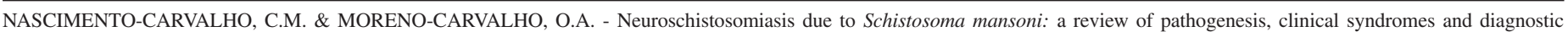
approaches. Rev. Inst. Med. trop. S. Paulo, 47(4):179-184, 2005.

after the systemic manifestations of the acute phase, which include fever, headache, malaise, anorexia, coughing, skin rash, diarrhea and abdominal pain (Katayama syndrome) ${ }^{16}$; patients may become confused, develop focal or generalized seizures or become stuporose and visual impairment and papilledema may occur; signs of encephalopathy such as hemiplegia and opisthotonus with extensor plantar responses or evidence of myelopathy such as ataxia, weakness of the legs, paraesthesiae, sensory loss and sphincter disturbances may also occur, even though, as a rule, neurological abnormalities resolve completely when the Katayama syndrome subsides in few days or weeks ${ }^{16,54,59}$. The presentation in pediatric patients is very similar to that observed in adults ${ }^{35}$.

\section{DIAGNOSIS}

The diagnosis of NS must be taken into account whenever a patient with history of exposure to schistosome-infected water presents either seizure, ataxia, increased intracranial pressure, hemianopsia, nystagmus and vertigo or paraplegia, sphincter dysfunction, and sensory disturbances from the pelvic girdle down, as these are the neurological alterations usually produced by cerebral or spinal cord NS, respectively ${ }^{46}$. The most frequent complaints in the spinal NS presentation are leg weakness, bladder dysfunction and low back pain $^{13,40,42}$. Confirmation of schistosomal infection by a direct method (stool parasitological examination and/or rectal biopsy for S. mansoni) and exclusion of other causes of the neurological damage are either required procedures for the presumptive diagnosis of $\mathrm{NS}^{16}$. Parasite eggs have been demonstrated frequently in a biologic specimen but difficulty in detection has not been uncommon ${ }^{13}$.

The CSF reflects very reliably the inflammatory process that compromises the spinal cord ${ }^{42}$. In 1985, LIVRAMENTO et al. ${ }^{28}$ described the syndrome of CSF in NS, which includes lymphomononuclear hypercellularity associated with the presence of eosinophils, an increase in protein concentration, and the presence of antibodies to $S$. mansoni. HABEEBULLA \& ROSS have recently reported a case of NS presenting with eosinophilic meningitis ${ }^{20}$. In a Brazilian series of 377 patients presumptively diagnosed with NS, hypercellularity was present in $66 \%$, protein concentration increase was identified in $84.6 \%$ and eosinophils were present in $46.9 \%{ }^{33}$. FERRARI et al. prospectively studying 63 patients with presumptive spinal NS found abnormal CSF (high protein concentration and/or pleocytosis) in $93.7 \%$, total protein concentration higher than $45 \mathrm{mg} /$ $\mathrm{dL}$ in $87.3 \%$, pleocytosis in $81.0 \%$ and presence of eosinophils in $57.1 \%{ }^{17}$. CAROD-ARTAL \& VARGAS have recently reported two cases with presumptive diagnosis of NS: one presented CSF pleocytosis, eosinophils, high protein levels and IgG positive for $S$. mansoni in CSF and other with a normal CSF study ${ }^{8}$. There have been few investigations into the serology of patients with NS. Serologic techniques such as complement fixation, hemagglutination inhibiting antibodies, immunofluorescence, Western blotting, and enzyme-linked immunosorbent assay (ELISA) have been used but none have yet achieved sufficient levels of sensitivity and specificity to justify their consideration as gold standard techniques ${ }^{38}$. Crude antigenic extracts of schistosomal materials are used in these tests ${ }^{58}$. Those immunodiagnostic techniques are, actually, well evaluated tools that can document the occurrence of Schistosoma infection in general. Furthermore, in $S$. mansoni-endemic regions, other illnesses that disturb the blood-brain barrier may lead to misdiagnosis of NS due to transference of Schistosoma antibodies from serum to CSF. MAGALHÃES-SANTOS et al. ${ }^{31}$ reported very recently the use of monoclonal antibodies of various immunoglobulin isotypes by ELISA to detect antibodies against $S$. mansoni soluble egg antigen (SEA) and soluble worm adult preparation (SWAP) in CSF and serum samples from patients suspected of having NS and from patients belonging to two control groups. In that investigation it was shown, for the first time, that different immunoglobulin classes and isotypes could be detected by ELISA in the CSF of patients with suspected NS. The authors also demonstrated that there was no cross-reaction in patients with neurocysticercosis or other neuropathies and IgG1 was the most discriminating isotype marker for the diagnosis of NS. In a study in Brazil, FERRARI et al. ${ }^{15}$ found the measurement of specific antibody responses in the CSF of presumptive cases of schistosomal myeloradiculopathy to be useful as only two, out of their controls, but 30 of their 54 presumptive cases had measurable CSF levels of IgG against SEA. Similar to other neurological infections, such as neurocysticercosis and neurosyphilis, it is believed that NS is associated with a mild-to-moderate degree of impairment of the blood-brain barrier along with intrathecal synthesis of antibodies ${ }^{29,48}$. Antibody production within the CNS is oligoclonal, suggesting that the plasma cells responsible for local antibody synthesis are derived from a limited number of B cells ${ }^{5,19,49}$. The use of CSF specific $\mathrm{IgG}$ index is highly recommended for the diagnosis of NS because it provides good separation of increased CNS IgG synthesis from immunoglobulin increase resulting from the altered permeability of the blood-brain barrier $^{14}$. An additional mean of diagnosing schistosome infection is the determination in ELISA of circulating anodic antigen (CAA) in the serum and CSF samples and of circulating cathodic antigen (CCA) in the serum ${ }^{61}$. In the study conducted by NAUS et al. $^{36}$, the detection of these types of circulating antigens in serum proved to be useful complementary diagnostic tools to the traditional microscopic examination of faeces for schistosome eggs. CAA is a gut-associated antigen that is excreted by adult worms in large quantities, and its concentrations are strongly associated with egg load and worm burden ${ }^{60}$.

Investigation of patients by the use of imaging techniques includes conventional water-soluble contrast myelography, computed tomography (CT), CT-myelography and Magnetic Resonance Image (MRI). CT-myelography may demonstrate enlargement of the conus medullaris or a complete CSF block in the lower thoracic or lumbar level; in some cases of transverse myelitis, conventional myelography, CT and CT-myelography are normal; affected nerve roots of the cauda equina may show irregular thickening and matting ${ }^{26}$. Myelography and CT may be normal in non severe cases or in patients with recent clinical complaints $^{23,56}$. By using MRI, SANELLI et al. ${ }^{51}$ described a linear and nodular enhancement pattern that was considered strongly suggestive of this infection, because it was not previously noted in other CNS worm infections or disease processes. These authors suggest that the unique "arborized" appearance of the linear and nodular enhancement pattern may constitute a new sign for the diagnosis of CNS schistosomiasis. Besides the enhancement of the medullar signal on MRI, a fine, diffuse, nodular contrast enhancement after gadolinium administration was described on the report of the fifth published case of cervical NS that was confirmed by biopsy of the spinal cord ${ }^{55}$. PEREGRINO et $a l .{ }^{41}$ reported that $88.8 \%$ of 18 patients with spinal NS presented weighted images and heterogenous pattern of 


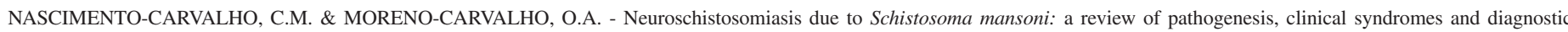
approaches. Rev. Inst. Med. trop. S. Paulo, 47(4):179-184, 2005.

enhancement with contrast material injection. CT/MRI findings of cerebral schistosomiais have been described as single or multiple hyperdense lesions with variable enhancement surrounded by lowdensity edema with an associated mass effect ${ }^{44}$, that is a punctuate enhancement and a heterogeneous internal structure which correlates with a moderately large granuloma due to the presence of a collection of eggs ${ }^{50}$. The eighth published case of cerebellar involvement in $S$. mansoni infection had contrast-enhanced images with a mass like structure and punctuate nodules on $\mathrm{MRI}^{7}$. MRI has been considered to be more sensitive than CT and both methods may show evidence of spinal cord atrophy in the later phase of the disease $\mathrm{e}^{9,21,56}$.

Definitive diagnosis of NS is based on the demonstration of eggs and or adult worms in the CNS tissue ${ }^{11}$. As spinal biopsy and laminectomy are invasive procedures requiring reliable imaging techniques, most of the cases described in the literature have the spinal cord compromised and have only been diagnosed presumptively, based on the coincidence of lower-cord neurological symptoms, evidence or a history of

Lower-cord neurological symptoms

\section{$+$}

Evidence or history of schistosome infection

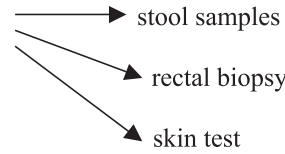

$+$

Exclusion of other causes of myelopathy

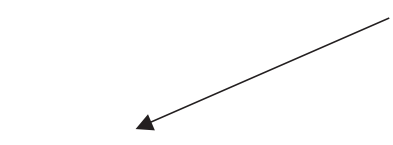

CSF: hypercellularity

increase in protein concentration

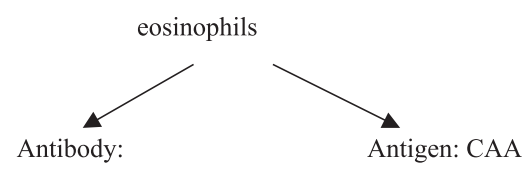

Complement fixation

Hemagglutination inhibiting

Immunofluorescence

Western blotting

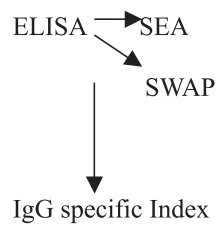

schistosome infection, exclusion of other causes of myelopathy and cerebrospinal fluid (CSF) examination and/or alterations in image studies $^{36}$. Presumptive diagnosis of cerebral NS is based on the coincidence of brain space-occupying lesions on CT or MRI, CSF alterations, evidence or a history of schistosome infection and exclusion of other causes of neurological disease ${ }^{14,36}$. Schistosomal infection is usually demonstrated by the presence of eggs in stool samples or rectal biopsy indicative of active infection ${ }^{36}$. Stool samples may be checked by using the quantitative Kato-Katz method ${ }^{24}$ and may be also checked using the more sensitive sedimendation method ${ }^{47}$. Infection by $S$. mansoni may be also investigated by the skin test that is usually positive in infected patients, even when live adult worms are no longer present ${ }^{2}$. The presumptive diagnosis of spinal NS according to the Centers for Disease Control and Prevention requires evidence of a low medullary lesion and/ or a lesion of the cauda equina, confirmation of schistosomiasis by stool parasitological examination and/or rectal biopsy or positive serological tests for schistosome and exclusion of other causes of the myeloradicular damage ${ }^{10}$. However, several authors have rejected the confirmation of schistosomal infection by serology since false-positive results are common because antibodies against schistosomal antigens can crossreact against antigens from other agents, particularly helminthes ${ }^{17}$. SANTOS et al. ${ }^{52}$ have proposed a classification for the probability of spinal NS: possible when there are low thoracic or lumbar/sacral spinal cord compromise and positive epidemiology for schistosomiasis; probable when besides the aforementioned criteria there are demonstration of schistosomal infection by parasitological methods and exclusion of other possible causes; confirmed when there is histopathological study of the CNS demonstrating the presence of $S$. mansoni ova or worm. These authors neither took into account CSF alterations nor image studies regarding NS diagnosis, though these probably are important tools for the presumptive diagnosis of NS. Algorithms are shown in Figures $1 \mathrm{~A}$ and $1 \mathrm{~B}$ presenting rationale sequences of procedures in order to investigate NS.

Increased intra-cranial pressure or focal signs

MRI: linear and nodular

enhancement pattern with

“arborized”appearance

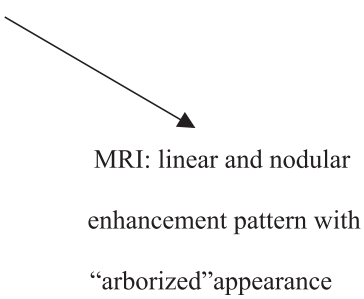

(a) 


\section{CONCLUSION}

Spinal cord schistosomiasis is one of the most severe forms of schistosomiasis in organ other than the digestive system and may lead to permanent neurological damage and even death, if left untreated ${ }^{36}$. The prevalence of schistosomal myelopathy is probably under-estimated and the disorder under-diagnosed ${ }^{14,23}$. A favorable outcome depends on early diagnosis with immediate treatment ${ }^{51}$ as this approach is frequently associated with a full recovery of all neurological functions ${ }^{37}$. Diagnosis remains difficult. The failure to detect schistosome eggs in stool and even a normal myelogram or MRI scan or CSF does not exclude schistosomiasis as a possible cause of myelopathy in adults and children. All efforts must be made in order to establish a presumptive or definite diagnosis, according to Figures $1 \mathrm{~A}$ and $1 \mathrm{~B}$.

\section{RESUMO}

\section{Neuroesquistossomose devido a Schistosoma mansoni: revisão da patogênese, síndromes clínicas e manejo diagnóstico}

Neuroesquistossomose (NS) é a segunda forma mais freqüente de apresentação da infecção causada pelo trematódeo Schistosoma mansoni. A inflamação do tipo granulomatosa ocorre como resultado da presença de ovos do $S$. mansoni que atingiram a medula espinhal ou o encéfalo via o sistema vascular ou pela migração inadvertida de vermes adultos para estes órgãos. Duas síndromes clínicas principais podem ser identificadas: a mielopatia esquistossomótica (aguda ou subaguda) e a neuroesquistossomose cerebral ou cerebelar localizada (comprometimento focal do Sistema Nervoso Central, convulsões, hipertensão intracraniana). O diagnóstico presumido da NS requer a confirmação da presença da infecção por exame microscópico de fezes ou pela biópsia retal em busca de ovos de trematódeo e testes sorológicos no sangue e no líquor. As lesões localizadas são identificadas por sinais e sintomas, e confirmadas por exames de imagem (mielografia contrastada, tomografia computadorizada e ressonância magnética). Algoritmos são apresentados para orientar uma avaliação diagnóstica seqüencial.

\section{REFERENCES}

1. ANDRADE, A.N. \& BASTOS, C.I. - Esquistossomose mansônica cerebral. Arq. Neuropsiquiat., 47: 100-104, 1989.

2. ANDRADE FILHO, A.S.; REIS, M.G.; SOUZA, A.L. et al. - Neuroesquistossomose mansônica. Aspectos clínicos, laboratoriais e terapêuticos. Arq. Neuropsiquiat., 54: 232-237, 1996.

3. ANDRADE, Z.A. - The situation of hepatosplenic schistosomiasis in Brazil today. Mem. Inst. Oswaldo Cruz, 93 (suppl. 1): 313-316, 1998.

4. ARAÚJO, M.I.; DE JESUS, A.R.; BACELLAR, O. et al. - Evidence of a T helper type 2 activation in human schistosomiasis. Europ. J. Immunol., 26: 1399-1403, 1996.

5. BLECK, T.P. \& GREENLEE, J.E. - Approach to the patient with central nervous system infection. In: MANDELL, G.L.; BENNETT, J.E. \& DOLIN, R., ed. Mandel, Douglas, and Bennett's principles and practice of infectious diseases. 5. ed. New York, Churchill Livingstone, 2000. p. 950-959.

6. BOROS, D.L. - Immunopathology of Schistosoma mansoni infection. Clin. Microbiol. Rev., 2: 250-269, 1989.

7. BRAGA, B.P.; COSTA JÚNIOR, L.B. \& LAMBERTUCCI, J.R. - Magnetic resonance imaging of cerebellar schistosomiasis mansoni. Rev. Soc. bras. Med. trop., 36: 635636, 2003.
8. CAROD ARTAL, F.J. \& VARGAS, A.P. - Myelopathy due to Schistosoma mansoni. A description of two cases and review of the literature. Rev. Neurol., 39: 137-141, 2004.

9. CAROD ARTAL, F.J.; VARGAS, A.P.; HORAN, T.A.; MARINHO, P.B. \& COELHO COSTA, P.H. - Schistosoma mansoni myelopathy: clinical and pathologic findings. Neurology, 63: 388-391, 2004.

10. CENTERS FOR DISEASE CONTROL AND PREVENTION - Acute schistosomiasis with transverse myelitis in American students returning from Kenya. M.M.W.R., 33(31): 446-447, 1984.

11. COHEN-GADOL, A.A.; ZIKEL, O.M.; MILLER, G.M. et al. - Spinal cord biopsy: a review of 38 cases. Neurosurgery, 52: 815-816, 2003.

12. CORRÊA, R.L.B.; LIMA, J.M.B.; ALENCAR, A.; BASTOS, I.C.C. \& DURO, L.A. Comprometimento neurológico na esquistossomose mansônica. Rev. bras. Neurol., 19: 101-104, 1983.

13. FERRARI, T.C. - Spinal cord schistosomiasis: a report of 2 cases and review emphasizing clinical aspects. Medicine (Baltimore), 78: 176-190, 1999.

14. FERRARI, T.C.; CORREA-OLIVEIRA, R.; XAVIER, A.P.; GAZZINELLI, G. \& CUNHA, A.S. - Estimation of the local synthesis of immunoglobulin $\mathrm{G}(\mathrm{IgG})$ in the central nervous system of patients with spinal cord schistosomiasis by the IgG index. Trans. roy. Soc. trop. Med. Hyg., 93: 558-559, 1999.

15. FERRARI, T.C.; MOREIRA, P.R.; OLIVEIRA, R.C. et al. - The value of an enzymelinked immunosorbent assay for the diagnosis of schistosomiasis mansoni myeloradiculopathy. Trans. roy. Soc. trop. Med. Hyg., 89: 496-500, 1995.

16. FERRARI, T.C. - Involvement of central nervous system in the schistosomiasis. Mem. Inst. Oswaldo Cruz, 99 (suppl. 1): 59-62, 2004.

17. FERRARI, T.C.; MOREIRA, P.R. \& CUNHA, A.S. - Spinal cord schistosomiasis: a prospective study of 63 cases emphasizing clinical and therapeutic aspects. J. clin. Neurosci., 11: 246-253, 2004.

18. FERREIRA, L.A.; LIMA, F.L.C.; ANJOS, M.R.O. \& COSTA, J.M.L. - A tumoral form of encephalic schistosomiasis: report of a case submitted to surgical treatment. Rev. Soc. bras. Med. trop., 31: 89-93, 1998.

19. FISHMAN, R.A. - Composition of the cerebrospinal fluid. In: FISHMAN, R.A., ed. Cerebrospinal fluid in diseases of the nervous system. 2. ed. Philadelphia, W.B. Saunders, 1992. p. 183-252.

20. HABEEBULLA, S. \& ROSS, J.J. - A Brazilian immigrant with spinal schistosomiasis. Infect. Med., 20: 555-558, 2003.

21. HARIBHAI, H.C.; BHIGJEE, A.I.; BILL, P.L. et al. - Spinal cord schistosomiasis: a clinical, laboratory and radiologic study, with a note on therapeutic aspects. Brain, 114: 709-726, 1991

22. HUGHES, A.J. \& BIGGS, B.A. - Parasitic worms of the central nervous system: an Australian perspective. Intern. Med. J., 32: 541-553, 2002.

23. JOUBERT, J.; FRIPP, P.J.; HAY, I.T.; DAVEL, G.H. \& VAN GRAAN, E.S.J. Schistosomiasis of the spinal cord - underdiagnosed in South Africa? S. Afr. med. J., 77: 297-299, 1990.

24. KATZ, N.; CHAVES, A. \& PELlEGRINO, J. - A simple device for quantitative stool thick-smear technique in schistosomiasis mansoni. Rev. Inst. Med. trop. S. Paulo, 14: 397-400, 1972.

25. LAMBERTUCCI, J.R.; ROCHA, R.S.; CARVALHO-ODOS, S. \& KATZ, N. Esquistossomose mansoni em Minas Gerais. Rev. Soc. bras. Med. trop., 20: 47-52, 1987.

26. LEITE, C.C.; SOUZA, A.F.; VALENTE, M.; ARAÚJO, M.A.N. \& JINKINS, J.R. - Clinics in diagnostic imaging (52). Spinal cord schistosomiasis. Singapore med. J., 41: 417-419, 2000. 


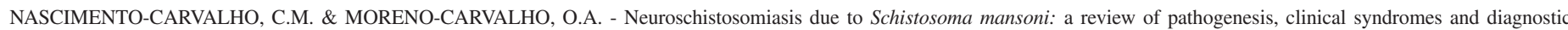
approaches. Rev. Inst. Med. trop. S. Paulo, 47(4):179-184, 2005.

27. LESPRIT, P.; ADLE-BIASETTE, H.; LIANCE, M. et al. - Photo quiz: cerebral S. mansoni infection. Clin. infect. Dis. 32: 1347-1371, 2001.

28. LIVRAMENTO, J.A.; MACHADO, L.R.; SILVA, C.L. \& SPINA-FRANÇA, A. Síndrome do líquido cefalorraqueano na neuroesquistossomose. Arq. Neuropsiquiat. (S. Paulo), 43: 372-377, 1985.

29. LIVRAMENTO, J.A.; MACHADO, L.R. \& SPINA-FRANÇA, A. - Sinalização do líquido cefalorroqueano em doenças inflamatórias crônicas do sistema nervoso central. Arq. Neuropsiquiat., 44: 351-358, 1986.

30. MACKENZIE, I.R. \& GUHA, A. - Manson's schistosomiasis presenting as a brain tumor. Case report. J. Neurosurg., 89: 1052-1054, 1998.

31. MAGALHÃES-SANTOS, I.F.; LEMAIRE, D.C.; ANDRADE-FILHO, A.S. et al. Antibodies to Schistosoma mansoni in human cerebrospinal fluid. Amer. J. trop. Med. Hyg., 68: 294-298, 2003.

32. MAHMOUD, A.A.F. - Trematodes (schistosomiasis) and other flukes. In: MANDELL, G.L.; BENNETT, J.E. \& DOLIN, R. ed. Mandel, Douglas, and Bennett's principles and practice of infectious diseases. 5. ed. New York, Churchill Livingstone, 2000. p. $2950-2953$.

33. MORENO-CARVALHO, O.A.; NASCIMENTO-CARVALHO, C.M.; BACELAR, A.L.S. et al. - Clinical and cerebrospinal fluid (CSF) profile and CSF criteria for the diagnosis of spinal cord schistosomiasis. Arq. Neuropsiquiat., 61 (2B): 353-358, 2003.

34. MWATHA, J.K.; KIMANI, G.; KAMAU, T. et al. - High levels of TNF, soluble TNF receptors, soluble ICAM-1, and IFN-gamma, but low levels of IL-5, are associated with hepatosplenic disese in human schistosomiasis mansoni. J. Immunol., 160: 1992-1999, 1998

35. NASCIMENTO-CARVALHO, C.M. \& MORENO-CARVALHO, O.A. - Clinical and cerebrospinal fluid findings in patients less than 20 years old with a presumptive diagnosis of neuroschistosomiasis. J. trop. Pediat., 50: 98-100, 2004.

36. NAUS, C.W.A.; CHIPWETE, J.; VISSER, L.G.; ZIJLSTRA, E.E. \& LIESHOUT, L.V. The contribution made by Schistosoma infection to non-traumatic disorders of the spinal cord in Malawi. Ann. trop. Med. Parasit., 97: 711-721, 2003.

37. NOBRE, V.; SILVA, L.C.S.; RIBAS, J.G. et al. - Schistosomal myeloradiculopathy due to Schistosoma mansoni: report on 23 cases. Mem. Inst. Oswaldo Cruz, 96 (suppl.): 137-141, 2001

38. PAMMENTER, M.D.; HARIBHAI, H.C.; EPSTEIN, S.R. et al. - The value of immunological approaches to the diagnosis of schistosomal myelopathy. Amer. J. trop. Med. Hyg., 44: 329-335, 1991.

39. PEARCE, E.; CASPAR, P.; GRZYCH, J.; LEWIS, F. \& SHER, A. - Downregulation of Th1 cytokine production accompanies induction of Th2 responses by a parasitic helminth, Schistosoma mansoni. J. exp. Med., 173: 159-166, 1991.

40. PEREGRINO, A.J.P.; OLIVEIRA, S.P.; PORTO, C.A. et al. - Meningomielorradiculite por Schistosoma mansoni. Arq. Neuro-psiquiat. (S. Paulo), 46: 49-60, 1988.

41. PEREGRINO, A.J.P.; PUGLIA, P.M.K.; BACHESCHI, L.A. et al. - Diagnosis of schistosomiasis of the spinal cord: contribution of magnetic resonance imaging and electroneuromyography. Arq. Neuropsiquiat., 60: 597-602, 2002.

42. PEREGRINO, A.J.P.; PUGLIA, P.M.K.; NÓBREGA, J.P.C. et al. - Esquistossomose medular: análise de 80 casos. Arq. Neuropsiquiat., 60: 603-608, 2002.

43. PITTELLA, J.E. \& LANA-PEIXOTO, M.A. - Brain involvement in hepatoesplenic schistosomiasis mansoni. Brain, 104: 621-632, 1981.

44. PITTELLA, J.E.; GUSMÃO, S.N.; CARVALHO, G.T.; DA SILVEIRA, R.L. \& CAMPOS, G.F. - Tumoral form of cerebral schistosomiasis mansoni: a report of cases and a review of the literature. Clin. Neurol. Neurosurg., 98: 15-20, 1996.
45. PITTELLA, J.E. - Neuroschistosomiasis. Brain Path., 7: 649-662, 1997.

46. PITTELLA, J.E. - The relation between involvement of the central nervous system in schistosomiasis mansoni and the clinical forms of parasitosis: a review. J. trop. Med. Hyg., 94: 15-21, 1991 .

47. POLDERMAN, A.M.; PANDAY, U.G.; RAMKISOEN, S.; VAN LIESHOUT, L. \& OOSTBURG, B.F. - A sedimentation-selective filtration method for the diagnosis of light infections with Schistosoma mansoni. Acta trop. (Basel), 58: 221-227, 1994.

48. REIS, J.B.; BEI, A. \& REIS-FILHO, J.B. - Síndromes do LCR. In: REIS, J.B.; BEI, A. \& REIS-FILHO, J.B., ed. Líquido cefalorraquiano. São Paulo, Sarvier, 1980. p. 171242.

49. REIS, J.B.; BEI, A. \& REIS-FILHO, J.B. - Semiologia do LCR. In: REIS, J.B.; BEI, A. \& REIS-FILHO, J.B., ed. Líquido cefalorraquiano. São Paulo, Sarvier, 1980. p. $63-$ 166.

50. ROPPER, A.H. \& STEMMER-RACHAMIMOV, A. - A 31-year-old man with an apparent seizure and a mass in the right parietal lobe. New Engl. J. Med., 345: 126-131, 2001

51. SANELLI, P.C.; LEV, M.H.; GONZALEZ, R.G. \& SCHAEFER, P.W. - Unique linear and nodular MR enhancement pattern in schistosomiasis of the central nervous system: report of three patients. Amer. J. Roentgenol., 177: 1471-1474, 2001.

52. SANTOS, E.C.; CAMPOS, G.B.; DINIZ, A.C.; LEAL, J.C. \& ROCHA, M.O. - Clinical profile and criteria for the diagnosis of schistosomal myeloradiculopathy. Arq. Neuropsiquiat., 59: 772-777, 2001

53. SCRIMGEOUR, E.M. - Non-traumatic paraplegia in northern Tanzania. Brit. med. J., 283: $975-978,1981$.

54. SCRIMGEOUR, E.M. \& GAJDUSEK, D.C. - Involvement of the central nervous system in Schistosoma mansoni and S. haematobium infection: a review. Brain, 108: $1023-$ 1038,1985

55. SILVA, L.C.S.; KILL, C.M. \& LAMBERTUCCI, J.R. - Cervical spinal cord schistosomiasis. Rev. Soc. bras. Med. trop., 35: 543-544, 2002.

56. SILVA, L.C.S.; MACIEL, P.E.; RIBAS, J.G.R. et al. - Schistosomal myeloradiculopathy Rev. Soc. bras. Med. trop., 37: 261-272, 2004.

57. STADECKER, M.J.; HERNANDEZ, H.J. \& ASAHI, H. - The identification and characterization of new immunogenic egg components: implications for evaluation and control of the immunopathogenic T cell response in schistosomiasis. Mem. Inst. Oswaldo Cruz, 96 (suppl.): 29-33, 2001.

58. TSANG, V.C. \& WILKINS, P.P. - Immunodiagnosis of schistosomiasis. Immunol. Invest. 26: $175-188,1997$.

59. URBAN, C.D.; PIOVESAN, E.J.; ALMEIDA, S.M. et al. - Acute schistosomiasis of the brain: case report. Arq. Neuropsiquiat., 54: 677-682, 1996.

60. VAN LIESHOUT, L.; POLDERMAN, A.M.; DE VLAS, S.J. et al. - Analysis of worm burden variation in human Schistosoma mansoni infections by determination of serum levels of circulating anodic antigen and circulating cathodic antigen. J. infect. Dis., 172: $1336-1342,1995$

61. VAN LIESHOUT, L.; POLDERMAN, A.M. \& DEELDER, A.M. - Immunodiagnosis of schistosomiasis by determination of the circulating antigens CAA and CCA, in particular in individuals with recent or light infections. Acta trop. (Basel), 77: 69$80,2000$.

62. WORLD HEALTH ORGANIZATION - Schistosomiasis. Geneva, World Health Organization, 1996. p. 1-4.

Received: 2 February 2005

Accepted: 2 June 2005 